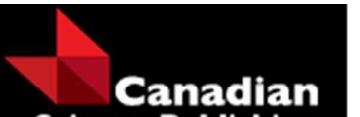

Science Publishing

Canadian Journal of Forest Research

Revue canadienne de recherche forestière

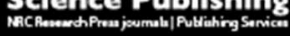

\title{
A cost analysis of bioenergy-generated ash disposal options in Canada
}

\begin{tabular}{|r|l|}
\hline Journal: & Canadian Journal of Forest Research \\
\hline Manuscript ID & cjfr-2016-0524.R1 \\
\hline Manuscript Type: & Article \\
\hline Date Submitted by the Author: & $27-$ Mar-2017 \\
\hline Complete List of Authors: & $\begin{array}{l}\text { Hope, Emily; Great Lakes Forestry Centre } \\
\text { Mckenney, Dan; Great Lakes Forestry Centre } \\
\text { Allen, Darren; Great Lakes Forestry Centre } \\
\text { Pedlar, John; Great Lakes Forestry Centre }\end{array}$ \\
\hline Keyword: & $\begin{array}{l}\text { Wood Ash Disposal, Cost Comparison, Landfill Disposal, Forest Application, } \\
\text { Canada }\end{array}$ \\
\hline $\begin{array}{r}\text { Is the invited manuscript for } \\
\text { consideration in a Special } \\
\text { Issue? : }\end{array}$ & \begin{tabular}{l} 
N/A \\
\hline
\end{tabular} \\
\hline
\end{tabular}

\section{SCHOLARONE \\ Manuscripts}


3 A cost analysis of bioenergy-generated ash disposal options in Canada

4

5

6 Emily S. Hope $^{1 \mathrm{a}}$, Daniel W. McKenney ${ }^{1 \mathrm{~b}}$, Darren J. Allen ${ }^{1 \mathrm{c}}$ and John H. Pedlar ${ }^{1 \mathrm{~d}}$

7

$8{ }^{1}$ Great Lakes Forestry Centre, Canadian Forest Service, Natural Resources Canada, Sault Ste.

9 Marie, Ontario, Canada, P6A 2E5

10

11 anEmily.Hope@Canada.ca

12 boan.McKenney@Canada.ca

13 DDarren.Allen@Canada.ca

14 dJohn.Pedlar@Canada.ca

15

16 Corresponding Author: Emily Hope

17

18 Email: Emily.Hope@Canada.ca

19 Telephone: 705-541-5570

20 Fax: 705-541-5712

21

22 Great Lakes Forestry Centre

231219 Queen Street East

24 Sault Ste. Marie, ON

25 P6A 2E5 


\section{Abstract}

27 The burning of wood for bioenergy produces significant amounts of ash residue which requires

28 disposal. We constructed a cost model to evaluate the unit costs of three ash disposal methods in

29 the Canadian context: landfills owned and operated by the bioenergy facility, municipal landfills,

30 and forest site application. The model accounts for costs related to the pre-treatment,

31 transportation, and disposal of ash at a landfill or forest site. Model parameter values were

32 assigned appropriate distributions (based on published literature and industry surveys) and

33 Monte Carlo simulations were employed to produce a range of model outputs for each disposal

34 option. Results indicate that existing landfills (if available for ash disposal) are likely the most

35 cost effective option (median value of \$77/tonne), although applying ash to a forest site is only

$36 \sim 15-20 \%$ more costly (median value of $\$ 92 /$ tonne). Indeed the unit cost estimates across disposal

37 options have considerable overlap. This suggests that close examination of firm specific

38 circumstances is highly warranted when choosing a disposal approach - even in the absence of

39 accounting for potential environmental benefits associated with forest-site disposal of ash.

41 Key Words:

42 Wood Ash Disposal, Cost Comparison, Landfill Disposal, Forest Application, Canada 


\section{$44 \quad$ Introduction}

45 The use of forest biomass to generate energy is expected to increase as governments aspire to 46 phase out traditional fossil fuels, and the demand for renewably sourced energy grows. While

47 bioenergy production may be beneficial for local economies and reduce greenhouse gas

48 emissions on some scales (Paré et al. 2011; Ter-Mikaelian et al. 2015), the waste-generating side

49 of bioenergy use is often ignored. Bioenergy ash, while rich in nutrients, is not yet re-purposed

50 (as coal ash is) on a large scale in Canada (McKenna pers.com. 2015), and is typically sent to

51 landfills (both in Canada and globally) (Brais et al. 2015; Freire et al. 2015; Hébert and Breton

52 2009). As the production of bioenergy and ash waste-products increase (Bradburn 2014), the

53 need for landfill capacity to accept ash will escalate as existing landfills reach or exceed their

54 capacities (Khan et al. 2016). This potentially undermines the environmental benefits typically

55 associated with bioenergy projects and adds important financial costs to be considered when

56 assessing the merits of alternative energy options.

57 The application of ash on recently harvested forest sites is an alternative to the landfill

58 approach and can generate a number of benefits, including: 1) return of nutrients removed from

59 the site during harvest (Nautiyal 1978); 2) reduced soil acidity due to the alkaline nature of the

60 applied ash; 3) potentially improved silvicultural yields (Augusto et al. 2008; Brais et al. 2015;

61 Väätäinen et al. 2011), and 4) expanded lifetime for existing landfills. The forest application of

62 ash is in fact practiced in some European and Scandinavian countries (Huotari et al. 2015), but

63 has gained little traction in Canada, despite historical precedent and agricultural use (Hérbert and

64 Breton 2009).

65 Here we examine financial factors associated with forest-based bioenergy ash disposal in

66 Canada. Specifically, we develop a spreadsheet-based model and estimate the present value unit 
67 costs of three different ash disposal methods: disposal in a landfill owned by the bioenergy

68 facility, disposal in a landfill owned by a local authority (e.g. municipal landfill), and ash

69 application to forest soils. Although the application of bioenergy ash to forest sites has been

70 studied from a variety of perspectives in Europe and Scandinavia (Augusto et al. 2008;

71 Börjesson 2000; Reid and Watmough 2013), very few conclusions can be applied to the

72 Canadian context, a direct result of differences in ash quality, forest management, governance,

73 and environmental factors (Augusto et al. 2008). We also provide what can be interpreted as a

74 break-even silvicultural application price per tonne of ash. This value is simply the difference in

75 the unit costs required to equalize the cost of forest site application with landfill disposal - a

76 useful metric that identifies what the benefits of the forest application would have to be in order

77 to justify forest applications versus the least cost alternative. The choice of this metric is further 78 justified below.

\section{Methods}

80 Model Overview

81 Our methods of estimating costs are similar to those used by Ramlal et al. (2009) in their net

82 present value (NPV) cost calculations regarding municipal biosolids, and Freeze et al. (1993)

83 manure-spreading cost estimates (see also Adhikari et al. 2005). The calculations presented here

84 examine only the financial costs associated with the three ash disposal options; economic

85 interpretations of benefits that might result from forest ash application are not considered due to

86 the lack of available information at this time. They are the subject of ongoing research.

87 We developed a spreadsheet-based model, augmented with the @Risk Monte Carlo

88 simulation program (@Risk v7.5, Palisade Co., Ithaca, NY 2016) to investigate the implications 
89 of various uncertainties. The model estimates the financial costs associated with the disposal of

90 ash in: 1) a producer-owned landfill, 2) a local or municipal landfill, and 3) on a forest site. Each

91 disposal option consists of specific cost categories thought to reflect the disposal processes; pre-

92 disposal treatment, transportation, and final disposal costs. These cost parameters are described

93 below and summarized in Table 1. Model outputs include the cost for each process, unit costs in

94 the form of total disposal cost per tonne of ash, and analysis of the key variables associated with

95 each cost estimate. Unit costs are a useful metric for decision-makers who face the task of

96 making their own subjective (and sometimes politically influenced) judgements about benefit

97 values and opportunity costs (McKenney et al. 2014). The following sub-sections provide details

98 about each component. Figure 1 outlines the model process.

99 Figure 1.

100

101 Pre-Disposal

Pre-disposal processing reflects the costs incurred to stabilize the ash and transform it into a

103 more useful, appropriate and/or acceptable form. Untreated ash from combustion facilities is

104 generally not suitable or acceptable for application on most soils in Canada due to its potentially

105 high reactivity (Arvidsson and Lundkvist 2003; Huotari et al. 2015). In addition, the dusty and

106 corrosive nature of untreated ash adds health and safety concerns (Väätäinen et al. 2011). Most

107 stabilization processes convert loose ash into less reactive forms, and reduce handling concerns

108 by increasing particle sizes (Ring et al. 2005). For our purposes, we assume that any ash applied

109 to the forest will be granulated, a process that mixes ash with water, creating a fertilizer-like

110 product (Väätäinen et al. 2011). We also assume that pre-disposal processing is not required for 
111 landfill disposal, given the limited concerns regarding nutrient leaching and harm to underlying 112 soils.

113 Total cost of the pre-disposal treatment is given by the product of the quantity of ash to be 114 processed, and the treatment fee on a per tonne basis:

115 [1] Total Pre - disposal Treatment Cost $=Q \times T$

116 where $Q$ is the quantity of ash to be disposed of in tonnes in a given year, and $T$ is the cost

117 associated with the selected pre-disposal treatment option (\$/tonne).

118 Transportation

119 Depending on the location of the bioenergy facility producing ash and the selected disposal

120 method, transportation costs may represent a considerable proportion of the total cost. Here we

121 consider transportation costs to be the expenses associated with moving the ash from the

122 production facility to the disposal site, inclusive of the fees associated with positioning the

123 transport to receive or to dump ash, loading and un-loading the ash, round trip transportation

124 distance, the number of trips to the disposal site, and road type. Because the disposal method

125 may vary between an easily accessible local landfill to a remote forest site, it is unrealistic to

126 assume that the road type used for transportation to each disposal site remains the same. Standard

127 forestry transportation models (Ljubic 1986; Smith and Tse 1977) typically assume that faster

128 speeds are achieved on well-maintained highways, while forest and gravel roads demand a

129 slower pace, thus incurring higher transportation costs. Transportation costs are calculated as

130 follows:

131 [2] Transportation Cost $=h\left(\left(E+R_{\text {Loaded }}+R_{\text {Empty }}\right) \times e\right)$ 
132 where $h$ is the hourly transportation cost in $\$ /$ hour, $E$ is the time spent loading and un-

133 loading the ash and positioning the transport in hours, $R_{\text {Loaded }}$ and $\mathrm{R}_{\text {Empty }}$ represent the time

134 travelled by a loaded and unloaded transport over different road classifications respectively, and

$135 \mathrm{e}$ is the annual number of trips required to transport the ash. $R_{\text {Loaded }}$ and $\mathrm{R}_{\text {Empty }}$ are further defined 136 below:

$$
[2.1] R_{\text {Loaded }}=\left(\frac{D_{H w y}}{S_{H w y}, L}\right)+\left(\frac{D_{\text {Primary }}}{S_{\text {Primary }, L}}\right)+\left(\frac{D_{\text {Secondary }}}{S_{\text {Secondary }, L}}\right)+\left(\frac{D_{\text {Tertiary }}}{S_{\text {Tertiary }, L}}\right)
$$

where $D$ is the distance travelled on each road classification and $S$ is the speed travelled on

139 each road type and is estimated based on loaded transport speeds. The equation for $R_{E m p t y}$ is 140 identical, using empty transportation speeds. $e$, the annual number of trips required to transport 141 the ash, is calculated as:

$142[2.2] e=\frac{Q}{\text { Truck capacity }}$

where Truck capacity is the weight of ash the transport vehicle is capable of carrying.

We assume that the majority of the transportation distance between an ash generating

145 facility and an owned landfill would take place on highway or primary roads. Similarly, we

146 anticipate that most of the transportation distance between a production facility and a municipal

147 landfill would take place on highways and higher road classifications. Transportation for forest

148 application is likely to encounter all four types of road classes, with the majority of distance

149 assumed to take place on highway classed roads.

150 Costs estimates for transportation are similarly structured across all three disposal options;

151 the options are differentiated by the processes and costs associated with disposal in landfills or

152 application on forest soils. Disposal costs for a producer-owned landfill are estimated as the net 
153 present value (NPV) of a combination of construction, maintenance, closure and monitoring

154 costs for a landfill. Disposal in a municipal landfill is expected to incur a tipping fee, as set by

155 the municipality. Application on a forest site requires the use of specialized machinery, which

156 must be transported to and from the site, and testing of the soil and ash for compatibility and

157 regulatory restrictions. The following sections highlight the unique assumptions about the pre-

158 disposal and transportation cost categories made for each disposal option and outline the disposal

159 cost estimates.

160 Disposal

161 Disposal in an Ash Producer-owned Landfill

162 Ash production facilities may not pay a tipping fee when disposal occurs in their own

163 landfill. However, landfilling costs still accumulate as a result of initial construction costs, yearly

164 maintenance costs, and end-of-life closure costs. Our model estimates somewhat simplified

165 lifetime costs for two possible scenarios - the first assuming a new landfill has to be constructed

166 for the sole purpose of receiving the ash waste, the second assuming that the landfill is already in

167 operation and only accepts ash. We use the net present value (NPV) lifetime cost to derive

168 landfill tipping fees (similar to Eilrich et al. 2003), expressed on a per tonne basis. The NPV

169 estimate for a new landfill includes construction and regulatory fees, maintenance costs over the

170 lifetime of the landfill, the costs of closure, and environmental monitoring fees for a period

171 following the end of the useful life of the landfill. Similar costs are incurred by an existing

172 landfill, but minus the initial construction costs, which are considered 'sunk costs' that do not

173 influence future decisions (Boardman et al. 2006)).

174 The total cost of ash disposal in the producer-owned landfill is calculated as: 
175 [3] Total Owned Landfill Disposal Cost $=L \times Q$

176 where $L$ is the per tonne disposal cost in an owned landfill, calculated as follows:

177

[3.1] $L=\frac{\left(\sum_{t=1}^{t_{\varphi}}\left(\frac{\varphi}{(1+i)^{t}}\right)+\sum_{t=t_{\varphi+1}}^{t_{\mu}}\left(\frac{\mu}{(1+i)^{t}}\right)+\sum_{t=t_{\mu}+1}^{t_{\omega}}\left(\frac{\omega}{(1+i)^{t}}\right)+\sum_{t=t_{\omega}+1}^{t_{m}}\left(\frac{m}{(1+i)^{t}}\right)\right) \times s}{d}$

where $\varphi$ is the cost associated with constructing a landfill (including the cost of obtaining

179 regulatory approval) over $t_{\varphi}$ years; $\mu$ is the fee associated with day to day operations of the

180 landfill, and is assumed to be incurred annually until the landfill closes at year $t_{\mu} . \omega$ are the

181 annual fees associated with closing the landfill and extend until shutdown is completed at year

$182 t_{\omega} ; m$ accounts for the annual costs of maintaining the land after active remediation activities

183 have ceased (i.e., maintaining fencing, monitoring groundwater, etc.) and continue until all

184 regulatory obligations have been met at year $t_{m} ; \varphi, \mu, \omega$, and $m$ are all expressed on a per hectare

185 basis, and $s$ represents the landfill area in hectares. The total producer-owned landfill disposal

186 cost is divided by the landfill capacity, represented by $d$, and expressed on a per tonne basis. The

187 year the landfill closes $\left(t_{\mu}\right)$ is calculated based on the landfill capacity and annual rate of ash

188 addition in tonnes, and is capped at 50 years:

$189[3.2] t_{\mu}=\frac{\text { Landfill Capacity }}{\text { Annual Rate of ash Added }}$

190 Ash producer-owned landfill disposal costs incurred over the partial lifetime of the landfill

191 are also discounted to the present. In this case, disposal costs are calculated similar to those

192 described above, but without the term in equation [3.1] that accounts for construction costs as

193 these are considered unrecoverable sunk costs in this scenario (Boardman et al. 2006). 
195 The costs of disposal in a local municipal landfill are estimated as the standard, non-

196 hazardous material tipping fee municipalities typically charge on a per tonne basis. For disposal

197 of ash, an additional regulatory cost has been included in the calculation. This fee reflects the

198 costs (monetary, opportunity and time) that may be encountered by a bioenergy facility while

199 seeking approval for ash disposal from provincial regulators and municipal authorities.

200 Experience within the industry suggests that some municipal authorities require additional

201 investment by the ash producer to upgrade existing municipal landfill facilities prior to disposal.

202 In some cases provincial landfill regulatory practices can also increase unit costs (Basiliko

203 pers.com. 2016, McKenna pers.com. 2015). Thus these costs are likely to vary significantly

204 across the country. Cost of disposal in a municipal landfill is calculated as:

205 [4] Total Municipal Landfill Cost $=r+(Q \times \tau)$

206 where $r$ is the regulatory fee associated with municipal disposal, and $\tau$ is the landfill tipping

207 fee. It is assumed that there are no restrictions on the amount of ash that can be deposited in a

208 municipal landfill.

209 Forest Application

210 Forest site ash application costs are estimated as a function of the amount of land intended

211 for ash application, equipment costs, application costs, and regulatory/testing fees. The amount

212 of forest land needed is a function of the per hectare amount of ash application, and the total

213 quantity of ash to be applied. Currently, there are no national regulations dictating the amount of

214 application of ash on forest soils, and provincial and territorial approaches to applying wood ash

215 on soils differ significantly (Deschamps 2015). Future regulations may result in more unified

216 provincial and territorial approaches by specifying the allowable quantity of ash applied to forest 
217 soils dependent on various environmental factors (Deschamps 2015) but ultimately this will

218 likely have some variation by jurisdiction.

219 Land suitable for application of ash is assumed to have been recently clear-cut, given that

220 application on newly forested sites can be expected to be much more costly. We have assumed

221 that numerous adjacent/aggregated parcels of clear-cut land will be used for ash application. For

222 each application site, ash-spreading equipment (similar to agricultural granular fertilizer

223 spreading equipment, (Brais et al. 2015)) must be delivered, un-loaded and loaded, and the soil

224 and ash must be tested for suitability. Equipment transportation costs are estimated assuming the

225 equipment must be transported from the bioenergy facility to the application site and back,

226 accounting for loaded transport speeds on various road classifications. The transportation costs

227 of moving spreading equipment between the actual forest sites have not been included here,

228 given the potential variation in distance between sites. In addition to the transportation costs, a

229 fee for equipment use per tonne per hectare is incurred, and a single regulatory fee is assumed to

230 reflect the costs (financial, opportunity, and time costs) of obtaining approval for ash application

231 from the appropriate authorities. The cost of applying ash to forest soils is calculated as:

232 [5] Total Forest Application Cost $=[g+($ Number of sites $\times \chi)+(\mathrm{A} \times Q)+$

\section{Float costs]}

234 where $g$ is the regulatory cost associated with obtaining approval for ash application,

235 Number of sites is the number of cut-blocks required to apply ash at the selected application rate,

$236 \chi$ is the cost of testing both the soil and the ash for compatibility, $A$ is the application cost on a

237 per tonne per hectare basis, representing equipment rental costs, salary and fuel costs for the

238 spreading operation only. Note that the application cost does not include the cost of transporting 
239 the spreading equipment to the cut-block (Nishio pers.com. 2015). Float Costs represent the

240 associated cost of transporting the spreading equipment to and from the cut-block sites for forest

241 application. The number of sites is calculated as:

$242 \quad[5.1]$ Number of sites $=\left(\frac{Q}{\rho}\right) \div \alpha$

243 where $\rho$ is the amount of ash application in tonnes per hectare, and $\alpha$ is the average cut-block

244 size. Float costs are calculated as:

245 [5.2] Float Costs $=($ Equipment transport time $+([$ Number of sites $\times(\theta+l)]) \times \kappa)$

246 where Equipment transport time is the time required to transport the spreading equipment to

247 and from the forest application site, $\theta$ is the time spent moving the spreading equipment onto

248 the ash application site (hours), $l$ is the time spent loading and unloading the equipment (hours),

249 and $\kappa$ is the equipment rental cost per hour incurred during transportation to and from the forest

250 application site. Equipment transport costs are calculated using Equation [2], with the

251 assumption that both the inbound and outbound transportation trips are calculated based on the

252 loaded speed.

\section{Data and Assumptions}

254 The costs associated with the disposal of ash are unique to every producer and every

255 disposal option. In an effort to account for some of the uncertainty associated with the data we

256 have gathered regarding costs for each option, all model variables have been assigned a

257 distribution of values, based on literature data and discussions with industry and government

258 representatives. As an additional benefit of the use of variable distributions, technical costs that

259 are not explicitly included within the analysis are implicitly captured within the cost ranges. The 
260 variables, their distributions and most likely values are illustrated in Table 1. Table 1 includes

261 data from pulp and paper mills and sawmills. The ash generated at these facilities is subject to

262 the same disposal constraints as ash produced by dedicated bioenergy facilities. Distributional

263 data for some variables are based on datasets that are large enough to identify appropriate

264 distributional shapes; for variables with smaller datasets, maximum, most likely, and minimum

265 values from the literature are used to assign triangular or uniform distributions. That said, it must

266 be recognized that in many respects some costs are subjective (Buchanan 1969) and unknowable

267 except to the individual decision-maker. Each firm will have its own cost circumstances; hence

268 here we provide a set of results based on our own assessment of costs (all expressed in 2014

269 Canadian dollars). More importantly we provide a framework for similar analyses. The

270 spreadsheet model is available upon request from the senior author.

271 Table 1.

272 Sensitivity Analysis

273 Using the base case data and assumptions discussed above, the cost per tonne of ash for each

274 of the disposal options is estimated as a single most likely value, and as a range of values

275 generated from the distributions assigned to the variables. This is achieved with the @ Risk

276 program. The program runs multiple iterations of the model, selecting different parameters for

277 each variable based on the assigned distributions. Table 1 summarizes the range of values used in

278 the sensitivity analyses.

279 Additionally, we examined three key model assumptions that affect the financial feasibility

280 of wood ash application on forest soils. Referencing the base case distributions, we evaluated

281 changes in pre-disposal treatment costs, adjustments to the acceptable rate of ash application on 
282 forest sites, and changes in the transportation distance between ash producers and forest sites

283 selected for ash application.

\section{Pre-Disposal Treatments}

285 There are few guidelines for the application of ash on forest lands, and no regulations 286 regarding pre-disposal treatments. These treatments could represent a considerable cost when 287 applying ash to forested soils. The base case assumes that the ash will be granulated prior to 288 application, although there are less expensive pre-disposal treatments available. Treatment costs

289 were varied from no-cost (no pre-treatment was required) to a mid-range cost (crushed ash), 290 inclusive of the high-cost base case assumption (granulated ash). Crushed ash is allowed to 291 harden (with the addition of water) into large blocks, and crushed into smaller pieces (Börjesson 292 2000; Pitman 2006). Granulated ash is generally considered to be of higher quality than crushed

293 ash, and is more costly due to the uniformity of the ash particle sizes and the potential

294 requirement for additional infrastructure.

\section{Forest Soil Ash Application Amount}

296 The per hectare amount of ash application on forest soils is not regulated in Canada, and the 297 quantity of ash that triggers a regulatory response is unknown for most jurisdictions. The initial 298 assumption of 2 tonnes of ash per hectare of forest soil was based on experience from both 299 Canadian and European literature (Arvidsson and Lundkvist 2003; Brais et al. 2015; Jacobson et 300 al. 2014). We varied ash application rates from 2 to 5 tonnes/ha to reflect a likely range of 301 possible application rates in future guidelines. The per hectare amount of ash application 302 influences a number of factors beyond the equipment cost associated with application. If a larger 
303 volume of ash can be applied to the site, less area will be needed to safely apply the ash, and 304 fewer soil tests will have to be conducted.

\section{Transportation Distance to Forest Site}

306 Transportation distances between bioenergy facilities and local landfills are unlikely to be 307 large, and should not vary substantially through time. Alternatively, forest application sites are 308 anticipated to be remote, and transportation distances are likely to change as forest sites are 309 treated with ash, and new forest sites are sought. Transportation distances for forest application 310 were varied between four triangular distributions of $\pm 25 \%$ with midpoints of $50 \mathrm{~km}, 100 \mathrm{~km}$,

$311250 \mathrm{~km}$, and $500 \mathrm{~km}$ to accommodate larger travel distances and the need to travel farther afield

312 to obtain new ash application sites. A transportation distance of $500 \mathrm{~km}$, although unlikely, has

313 been included to highlight the costs associated with extreme transportation distances.

\section{Results}

\section{Base Model Outputs}

316 Results from the base model runs indicate that disposal in an ash producer-owned landfill

317 part way through its lifecycle was generally the least costly option, followed by (in order of

318 increasing cost) application of wood ash onto forest soils, ash disposal in a municipal landfill,

319 and construction of a new on-site landfill. Table 2 presents the cost estimates for each disposal

320 option and the break-even price that would be required to make forest application attractive to an

321 ash producer relative to the more traditional landfilling approach. In this case, an ash producer

322 using an existing owned landfill would require an additional \$15/tonne payment before being

323 indifferent between forest application and continued use of the landfill. 
324 Table 2.

325 Figure 2 illustrates the distribution of the model outputs associated with each disposal

326 option. Of particular note is the range of variation within the cost distributions -the forest

327 disposal option was associated with the least variation and the municipal landfill option was

328 associated with the greatest variation. This variation is driven by the range of parameter input

329 values associated with each disposal option (see Table 1). The contribution of specific model

330 parameters to this variation is examined in the sensitivity analyses below.

331 Figure 2.

332

333 Sensitivity Analysis Results

334 Figure 3 highlights the most influential variables associated with each disposal option. For a

335 landfill owned and operated by a bioenergy facility, both the discount rate, and the size (area and

336 capacity) of the landfill are key parameters, regardless of whether the landfill is partially through

337 its lifespan, or has yet to be constructed. Not surprisingly, the cost of disposal in a municipal

338 landfill is overwhelmingly dictated by the municipal tipping fee. The cost of pre-disposal

339 treatment (granulation in the base case) strongly influences the final cost of forest application.

$340 \quad$ Figure 3.

$341 \quad$ Pre-disposal Treatments

342 Pre-disposal treatments represent a significant cost for wood ash disposal. When pre-

343 disposal treatment costs are eliminated, ash application on forest sites is the cheapest disposal

344 option (Fig. 4). Total costs for this scenario reflect transportation and application, estimated from 
$345 \$ 6.38$ to $\$ 48.17 /$ tonne of ash. Crushing ash as a pre-disposal treatment is also a low cost option, 346 resulting in total costs of approximately $\$ 21.01$ to $\$ 67.23 /$ tonne of ash (Fig. 4). In the event that

347 there is no need for pre-disposal treatment, or that crushed ash is sufficient for forest application, 348 forest application is likely to be the most cost effective ash disposal method.

$349 \quad$ Figure 4.

$350 \quad$ Forest Soil Ash Application Amount

351 The impact of increasing the ash application amount from 2 tonnes/ha (in the base case) to 3 ,

3524 , and 5 tonnes/ha was minimal. As the per hectare amount of ash application increased, the cost

353 distribution shifted to the left, consistent with the expectation that costs would decline with

354 higher application rates. However, the magnitude of these changes was small, due to the

355 relatively minor contribution that application costs make to total disposal costs (Table 2, Fig. 3).

\section{Transportation Distance to Forest Site}

357 Variation in the transportation distance to the forest sites influenced both the initial ash

358 transport cost, and the cost of transporting ash spreading equipment to and from the forested site.

359 We investigated a range of transportation distances from 50 to $500 \mathrm{~km}$ (Fig. 5). As the

360 transportation distance increased, the cost distribution shifted to the right and broadened. This is

361 a result of the combined effect of increasing ash and spreading equipment transport costs, and the

362 increasing proportion of total costs related to transportation.

\section{Figure 5.}

\section{Discussion and Concluding Comments}


365 Our findings indicate that, under average conditions, ash disposal in an existing producer-

366 owned landfill is the most economically attractive disposal method. Alternatively, the costs of

367 applying ash on forest sites are only slightly higher than those associated with disposal in an

368 existing producer-owned landfill, suggesting that ash application on forest sites offers a viable

369 alternative to the landfilling approach. Disposal in a municipal landfill and disposal in a newly

370 constructed producer-owned landfill appear to be more costly options. However, given the wide

371 range of outcomes identified here, selection of an appropriate ash disposal option will depend on

372 the unique set of economic factors associated with a given bioenergy production facility.

373 Furthermore, our findings suggest limited variation in the cost estimates for forest site

374 application when compared to the cost estimates for other disposal methods. The wide range in

375 cost estimates for landfilling practices is a result of the uncertainty associated with landfill

376 parameters and the significant variation observed within the industry. Landfills surveyed

377 typically varied in size, capacity, lifespan and tipping fees. Additional variation in cost estimates

378 stems from construction, maintenance, closure and post-closure monitoring costs. Costs

379 associated with landfills are highly site specific (Eilrich et al. 2003), and therefore vary

380 considerably.

381 While average costs for forest application were modestly higher ( $\$ 15 /$ tonne of ash) than the

382 costs associated with disposal in an existing producer-owned landfill, there are a number of

383 avenues that could be explored to further reduce costs related to forest application. Reducing the

384 costs associated with pre-disposal treatment of the ash would significantly improve the economic

385 attractiveness of forest application. The model assumed that ash from biomass combustion

386 facilities was treated to improve stability and usefulness prior to application on forest sites.

387 Variations in this assumption have highlighted potential cost savings with different approaches to 
388 ash pre-disposal treatment. Reductions in the cost of ash treatment would improve the financial 389 feasibility of forest application.

390 Additionally, spreading ash on local forest sites within a certain distance from the ash 391 production facility will ensure that forest site application remains somewhat competitive with

392 landfill disposal options. Based on the assumptions made here, forest application transportation 393 distances can be extended to approximately $100 \mathrm{~km}$ prior to increasing total costs such that

394 municipal landfill disposal becomes more financially attractive. Moderate increases in 395 transportation distance result in significant increases in cost due to the compounding effects of 396 transporting ash and spreading equipment.

We did not consider costs/losses that may occur when granulated ash is unloaded at the forest 398 disposal site. Depending on the situation, the granulated ash will likely need to be temporarily 399 stored in piles prior to spreading (Kopecky et al. 2014), which could lead to wastage.

400 Alternatively, the granulated ash could be packed in sacks prior to transport (Väätäinen et al. 401 2011); this would likely reduce wastage at time of unloading, but incur costs related to the 402 packaging. While future modelling efforts may attempt to incorporate these considerations, we 403 feel that their overall economic impact is relatively minor and should be contained within the 404 bounds of the sensitivity analysis employed here.

Although wood ash application on forest sites is economically feasible under some 406 circumstances, the effects of the regulatory environment cannot be ignored. The regulations that 407 currently govern soil additives vary by province, and are not designed for biomass ash 408 application on forest sites (Deschamps 2015). There is no formal approval process currently 409 available to proponents interested in forest application, and the existing regulatory process are 
410 perceived to be expensive and time consuming (Rutherford, pers.com. 2016). These factors

411 impose significant barriers and may discourage forest site applications. Representative costs of

412 obtaining regulatory approval have been included in the model and are based on discussions with

413 industry.

414 Disposing of ash in existing producer-owned landfills will continue to be the most cost

415 effective option for ash producers without acknowledgement of the social and environmental

416 costs and benefits associated with landfilling or forest site application. The break-even values

417 calculated to encourage adoption of forest soil ash applications highlight the minimum

418 monetized value (approximately \$15/tonne of ash or more) of environmental services necessary

419 to make ash producers indifferent between traditional disposal methods and forest soil

420 application.

421 Future research could estimate the monetized value of environmental services accruing from

422 forest soil application of wood ash. Scandinavian literature has suggested that the return of

423 nutrients removed from the forest site during harvest may help to improve silvicultural yields and

424 the application of alkaline ash to acidic soils may increase soil nutrient availability (Augusto et

425 al. 2008; Brais et al. 2015; Staples and Rees 2001; Väätäinen et al. 2011). Additional non-forest

426 benefits may also include extension of existing landfill lifetimes, and delaying the creation of

427 new landfills and their associated social costs. 
432 Funding for this work came from Natural Resources Canada Program of Energy Research and 433 Development (PERD). We would like to thank the pulp and paper and utility industries of British 434 Columbia, Ontario and Nova Scotia for graciously answering our wood ash disposal questions. 


\section{References}

436 Adhikari, M., Paudel, K.P., Martin, N.R., Gauthier, W.M. 2005. Economics of dairy waste use as 437 fertilizer in central Texas. Waste Manag. 25:1067-1074. doi:10.1016/j.wasman.2005.06.012.

438 Arvidsson, H., Lundkvist, H. 2003. Effects of crushed wood ash on soil chemistry in young 439 Norway spruce stand. For Ecol Manag. 176:121-32.

440 Augusto, L., Bakker, M.R., Meredieu, C. 2008. Wood ash applications to temperate forest 441 ecosystems - potential benefits and drawbacks. Plant and Soil. 306(1-2):181-98. doi: $10.1007 / \mathrm{s} 11104-008-9570-\mathrm{z}$.

443 Boardman, A.E., Greenberg, D.H., Vining, A.R., Weimer, D.L. 2006. Cost-Benefit Analysis 444 Concepts and Practice. $3^{\text {rd }}$ ed. Prentice Hall, Upper Saddle River, NJ. pp. 560.

445 Börjesson, P. 2000. Economic valuation of the environmental impact of logging residue recovery 446 and nutrient compensation. Biomass Bioener. 19:137-52.

447 Bradburn, K. 2014. 2014 CanBio report on the status of bioenergy in Canada. Canadian $448 \quad$ Bioenergy Association. p. 96.

449 Brais, S., Bélanger, N., Guillemette, T. 2015. Wood ash and N fertilization in the Canadian $450 \quad$ boreal forest: Soil properties and response of jack pine and black spruce. For Ecol Manag. $451 \quad 348: 1-14$. doi:10.1016/j.foreco.2015.03.021.

452 Buchanan, J.M. 1969. Cost and Choice - An Inquiry in Economic Theory. The University of 453 Chicago Press, Chicago, IL. 
454 Deschamps, C. 2015. Canadian regulations and guidelines for wood ash waste disposal: a 455 review. Report from the Great Lakes Forestry Centre.

456 Duffy, D.P. 2016. Landfill economics: getting down to business - Part 2. [online]. Forest Daily 457 News. Available from http://foresternetwork.com/daily/waste/landfill-management/landfill458 economics-part-ii-getting-down-to-business-part-i/ [accessed 05.12.2016].

459 Eilrich, F.C., Doeksen, G.A., Van Fleet, H. 2002. An economic analysis of landfill costs to 460 demonstrate the economies of size and determine the feasibility of a community owned 461 landfill in rural Oklahoma. In Southern Agricultural Economics Association Annual 462 Meeting, Alabama, 1-5 February 2003. p.19.

463 Freeze, B.S., Webber, C., Lindwall, C.W., Dormaar, J.F. 1993. Risk simulation of the economics 464 of manure application to restore eroded wheat cropland. Can J Soil Science.73:267-74.

465 Freire, M., Lopes, H., Tarelho, L.A.C. 2015. Critical aspects of biomass ashes utilization in soils: 466 Composition, leachability, PAH and PCDD/F. Waste Manag. 46:304-315. doi: $467 \quad$ 10.1016/j.wasman.2015.08.036.

468 Government of Ontario. Application fees for environmental compliance approvals [online]. 469 Available from https://www.ontario.ca/page/ministers-requirement-fees-ecas [accessed $470 \quad 30.11 .2015]$

471 Hébert, M., Breton, B. 2009. Agricultural wood ash recycling in Quebec and in northern 472 climates: current situation, impacts and agri-environmental practices. 5th Canadian 473 Residuals and Biosolids Conference. Niagara Falls, Ontario. p. 34. 
474 Huotari, N., Tillman-Sutela, E., Moilanen, M., Laiho, R. 2015. Recycling of ash - For the good 475 of the environment?. For Ecol Manag. 348:226-40. doi:10.1016/j.foreco.2015.03.008

476 Jacobson, S., Lundström, H., Nordlund, S., Sikström, U., Pettersson F. 2014. Is tree growth in 477 boreal coniferous stands on mineral soils affected by the addition of wood ash?. Scand J 478 Forest Res. 29(7): 675-685. doi:10.1080/02827581.2014.959995.

Khan, M.M., Jain, S., Vaezi, M., Kumar, A. 2016. Development of a decision model for the techno-economic assessment of municipal solid waste utilization pathways. Waste Manag. 48:548-564. doi:10.1016/j.wasman.2015.10.016.

Kopecky, J.M., Meyers, N.L., Wasko, W. 2014. Using industrial wood ash as a soil amendment. University of Wisconsin - Extension Technical Report No. A3635. Madison, WI.

Lavoic, J.M. 1979. The Transportation of Tree Lengths by Truck Trains. Forest Research Institute of Canada Technical Report No. TR-33. Pointe Claire, Quebec.

Ljubic, D.A. 1982. Simplified method for calculating road hauling costs for transport unit alternatives. Forest Research Institute of Canada Technical Note TN-95. Pointe Claire, Quebec.

McKenney, D.W., Weersink, A., Allen, D., Yemshanov, D., Boyland, M. 2014. Enhancing the adoption of short rotation woody crops for bioenergy production. Biomass Bioener. 64:3636. doi:10.1016/j.biombioe.2014.03.040. 
493 Ontario Ministry of Natural Resources and Forestry. 2014. Forest Management Annual

494 Reporting Data [online]. Available from

495 https:/www.javacoeapp.lrc.gov.on.ca/geonetwork/srv/en/main.home?uuid=7f5ee342-5c9f-

496 4613-85f3-d035d365b248 [accessed 24 November 2015].

497 Paré, D., Bernier, P., Thiffault, E., Titus, B.D. 2011. The potential of forest biomass as an energy 498 supply for Canada. For Chron. 87(1):71-6. doi:10.5558/tfc87071-1.

499 Pitman, R. 2006. Wood ash use in forestry; a review of the environmental impacts.

500 Environmental and Human Sciences Division, Forest Research, Alice Holt Lodge, Surry, $501 \quad$ England.

502 Smith, D.G., Tse, P.P. 1977. Logging trucks: comparison of productivity and costs. Vancouver, 503 B.C.: Forest Engineering Research Institute of Canada.

504 Staples, T.E., Van Rees, K.C.J. 2001. Wood/sludge ash effects on white spruce seedling growth. 505 Can J of Soil Science. 8(1):85-92. doi:10.4141/S00-014.

506 Ramlal, E., Yemshanov, D., Fox, G., McKenney, D.W. 2009. A bioeconomic model of 507 afforestation in Southern Ontario: integration of fiber, carbon and municipal biosolids values. J Environ Manag. 90(5):1833-43. doi:10.1016/jenvman.2008.11.029.

509 Reid, C., Watmough, S.A. 2014. Evaluating the effects of liming and wood-ash treatment on 510 forest ecosystems through systematic meta-analysis. Can. J. For. Res. 44: 867-885. doi: $511 \quad 10.1139 /$ cfjr-2013-0488. 
512 Ring, E., Jacobson, S., Nohrstedt, H.O. 2005. Soil-solution chemistry in a coniferous stand after

513 adding wood ash and nitrogen. Can. J. For. Res. 36: 153-163. doi: 10.1139/X05-242.

514 Ter-Mikaelian, M.T., Colombo, S.J., Lovekin, D., McKechnie, J., Reynolds, R., Titus, B.D.,

515 Laurin, E., Chapman, A.M., Chen, J., Maclean, H.L. 2015. Carbon debt repayment or

516 carbon sequestration parity? Lessons from a forest bioenergy case study in Ontario, Canada.

517 GCB Bioener. 7:704-16. doi:10.111/gcbb.12198.

518 The University of Wisconsin Madison. Soil and Plant Analysis Laboratory Fees/Brochure

519 [online]. Available from http://uwlab.soils.wisc.edu/fees/ [accessed 22.10.2015].

520 Väätäinen, K., Sirparanta, E., Räisänen, M., Tahvanainen, T. 2011. The costs and profitability of $521 \quad$ using granulated wood ash as a forest fertilizer in drained peatland forests. Biomass Bioener. $522 \quad 35(8): 3335-41$. doi:10.1016/j.biombioe.2010.09.006. 
Table 1: Summary of model variables and assigned distributions used in the model.

\begin{tabular}{|c|c|c|c|c|}
\hline Variable & $\begin{array}{l}\text { Most Likely } \\
\text { Values }\end{array}$ & $\begin{array}{l}\text { @Risk Distribution } \\
\text { Values }\end{array}$ & $\begin{array}{c}\text { @Risk } \\
\text { Distribution }\end{array}$ & Comments \\
\hline Quantity of Ash Disposed & 1,000 tonnes & - & & $\begin{array}{l}\text { Model assumes } 1,000 \text { tonnes of ash } \\
\text { disposed under each option }\end{array}$ \\
\hline \multicolumn{5}{|l|}{ Pre-disposal Processing } \\
\hline Crushing & $\$ 18.70$ & $\$ 12.50$ - \$24.90/tonne & Triangular & Börjesson 2000 \\
\hline Granulation & $\$ 73.00$ & $\$ 49.60$ - $\$ 95.80 /$ tonne & Triangular & Börjesson 2000 \\
\hline \multicolumn{5}{|l|}{ Transportation } \\
\hline Truck Capacity & 38 tonnes & $30-54$ & Triangular & Smith and Tse 1977 and Nishio 2015 \\
\hline $\begin{array}{l}\text { Distance (Ash producer } \\
\text { owned landfill) }\end{array}$ & - & $1-5 \mathrm{~km}$ & Uniform & $\begin{array}{l}\text { Discussions with industry suggest that } \\
\text { producer-owned landfills are typically } \\
\text { adjacent to or within } 5 \mathrm{~km} \text { of production } \\
\text { facilities }\end{array}$ \\
\hline $\begin{array}{l}\text { Distance (Municipal } \\
\text { landfill) }\end{array}$ & - & $1-50 \mathrm{~km}$ & Uniform & $\begin{array}{l}\text { Distance from the ash production facility } \\
\text { to the municipal landfill may vary } \\
\text { randomly }\end{array}$ \\
\hline $\begin{array}{l}\text { Distance (Forest } \\
\text { application) }\end{array}$ & - & $1-100 \mathrm{~km}$ & Uniform & $\begin{array}{l}\text { Distance from the ash production facility } \\
\text { to the forest application site may vary }\end{array}$ \\
\hline Loading Time & 0.67 hour & 0.33 - 1 hour & Triangular & Nishio 2015 \\
\hline Un-Loading Time & 0.17 hour & $0.08-0.25$ hour & Triangular & Nishio 2015 \\
\hline Turn-around Time & 0.13 hour & $0.08-0.17$ hour & Triangular & Nishio 2015 \\
\hline $\begin{array}{l}\text { Variable Transportation } \\
\text { Costs }\end{array}$ & $\$ 86.80$ & $\begin{array}{l}\$ 48.60-\$ 125.00 \text { per } \\
\text { hour }\end{array}$ & Triangular & $\begin{array}{l}\text { Lavoic 1979, Ljiubic 1986, and Nishio } \\
2015\end{array}$ \\
\hline $\begin{array}{l}\text { Road Type Speed, Loaded } \\
\text { (Highway) }\end{array}$ & $75.00 \mathrm{~km} / \mathrm{h}$ & $50.00-100.00 \mathrm{~km} / \mathrm{h}$ & Triangular & $\begin{array}{l}\text { Lavoic 1979, Ljiubic 1986, and Nishio } \\
2015 .\end{array}$ \\
\hline $\begin{array}{l}\text { Road Type Speed, Loaded } \\
\text { (Primary) }\end{array}$ & $62.80 \mathrm{~km} / \mathrm{h}$ & $50.90-75.00 \mathrm{~km} / \mathrm{h}$ & Triangular & $\begin{array}{l}\text { Lavoic 1979, Ljiubic 1986, and Nishio } \\
2015 .\end{array}$ \\
\hline
\end{tabular}




\begin{tabular}{|c|c|c|c|c|}
\hline $\begin{array}{l}\text { Road Type Speed, Loaded } \\
\text { (Secondary) }\end{array}$ & $44.80 \mathrm{~km} / \mathrm{h}$ & $36.50-55.00 \mathrm{~km} / \mathrm{h}$ & Triangular & $\begin{array}{l}\text { Lavoic 1979, Ljiubic 1986, and Nishio } \\
2015 .\end{array}$ \\
\hline $\begin{array}{l}\text { Road Type Speed, Loaded } \\
\text { (Tertiary) }\end{array}$ & $25.20 \mathrm{~km} / \mathrm{h}$ & $18.30-31.20 \mathrm{~km} / \mathrm{h}$ & Triangular & $\begin{array}{l}\text { Lavoic 1979, Ljiubic 1986, and Nishio } \\
2015 .\end{array}$ \\
\hline $\begin{array}{l}\text { Road Type Speed, Empty } \\
\text { (Highway) }\end{array}$ & $87.50 \mathrm{~km} / \mathrm{h}$ & $75.00-100.00 \mathrm{~km} / \mathrm{h}$ & Triangular & $\begin{array}{l}\text { Lavoic 1979, Ljiubic 1986, and Nishio } \\
2015 .\end{array}$ \\
\hline $\begin{array}{l}\text { Road Type Speed, Empty } \\
\text { (Primary) }\end{array}$ & $68.30 \mathrm{~km} / \mathrm{h}$ & $53.80-80.00 \mathrm{~km} / \mathrm{h}$ & Triangular & $\begin{array}{l}\text { Lavoic 1979, Ljiubic 1986, and Nishio } \\
2015 .\end{array}$ \\
\hline $\begin{array}{l}\text { Road Type Speed, Empty } \\
\text { (Secondary) }\end{array}$ & $52.10 \mathrm{~km} / \mathrm{h}$ & $42.50-62.50 \mathrm{~km} / \mathrm{h}$ & Triangular & $\begin{array}{l}\text { Lavoic 1979, Ljiubic 1986, and Nishio } \\
2015 .\end{array}$ \\
\hline $\begin{array}{l}\text { Road Type Speed, Empty } \\
\text { (Tertiary) }\end{array}$ & $30.70 \mathrm{~km} / \mathrm{h}$ & $24.00-37.00 \mathrm{~km} / \mathrm{h}$ & Triangular & $\begin{array}{l}\text { Lavoic 1979, Ljiubic 1986, and Nishio } \\
2015 .\end{array}$ \\
\hline \multicolumn{5}{|l|}{ Disposal Costs } \\
\hline \multicolumn{5}{|c|}{ Ash producer-owned Landfill Disposal } \\
\hline Discount Rate & $4 \%$ & $2 \%-8 \%$ & Triangular & \\
\hline Pre-Construction Costs & $\$ 300,000$ & $\begin{array}{l}\$ 200,000-\$ 400,000 \\
\text { /landfill }\end{array}$ & Triangular & Nishio 2015 \\
\hline $\begin{array}{l}\text { New Site Construction } \\
\text { Costs }\end{array}$ & $\$ 1,499,260$ & $\begin{array}{l}\$ 817,778- \\
\$ 2,180,741 / \mathrm{yr}\end{array}$ & Triangular & Duffy 2016 \\
\hline Maintenance Costs & $\$ 86,790$ & $\$ 55,493$ - $\$ 118,090 / \mathrm{yr}$ & Triangular & Duffy 2016 \\
\hline Remediation Costs & $\$ 920,080$ & $\begin{array}{c}\$ 477,200- \\
\$ 1,362,962 / \mathrm{yr}\end{array}$ & Triangular & Duffy 2016 \\
\hline Post-Closure Costs & $\$ 9,350$ & $\$ 120-\$ 18,580 / y r$ & Triangular & Duffy 2016 \\
\hline Total Landfill Area & 19.55 ha & $6.10-33$ ha & Triangular & $\begin{array}{l}\text { Based on interviews of random pulp and } \\
\text { paper and saw mills across British } \\
\text { Columbia, Ontario and Nova Scotia }\end{array}$ \\
\hline Total Landfill Capacity & 409,667 tonnes & $\begin{array}{l}252,000-597,000 \\
\text { tonnes }\end{array}$ & Triangular & $\begin{array}{l}\text { Based on interviews of random pulp and } \\
\text { paper and saw mills across British } \\
\text { Columbia, Ontario and Nova Scotia }\end{array}$ \\
\hline $\begin{array}{l}\text { Annual Rate of Ash } \\
\text { Addition }\end{array}$ & 15,360 tonnes/yr & $3,000-27,000$ tonnes/yr & Triangular & $\begin{array}{l}\text { Based on interviews of random pulp and } \\
\text { paper and saw mills across British } \\
\text { Columbia, Ontario and Nova Scotia }\end{array}$ \\
\hline
\end{tabular}


Remaining Storage

Lifetime

Landfill Construction

Period

Regulatory Fees

Landfill Disposal Fee

Average Cut-Block Size

Regulatory Fees

Site Soil Testing

Ash Testing

Float Equipment Rental Costs

Time spent moving ash spreading equipment onto application site

Float Loading and Offloading Time

Application Cost
$\$ 99.60$ per tonne

$\$ 12.75$ - \$220 per tonne

\section{Forest Application}

50 years

1 year

Municipal Landfill Disposal

$\$ 6,000$ per landfill

$\$ 0$ - $\$ 10,000$ per landfill

Triangular

4 - 100 hectares

$\$ 0-\$ 15,000$

$\$ 7,823.60$

$\$ 76.40$ per site

$\$ 39.80$ per site

$\$ 112.50$ per hour

0.13 hour

0.21 hour

$\$ 4.80$ per tonne per
Lifetime capped to reflect changes in regulation and industry

Construction period limited to one year for simplicity

Application fees for environmental compliance approvals under the

Environmental Protection Act

(Government of Ontario, N.D.)

Value range established based on a random sample of 15 municipal landfills from three provinces: British Columbia, Ontario and Nova Scotia

Based on 2002 to 2013 cut-block data from the Ontario Ministry of Natural Resources and Forestry (OMNRF, 2014) Based on comments from UNBC Aleza

Lake Ash Testing Site (Rutherford, pers. com. 2016)

The University of Wisconsin Madison (2012)

The University of Wisconsin Madison

\section{(2012) \\ $\$ 35.80$ - $\$ 43.90$ per site \\ Triangular \\ $\$ 90$ - \$135 per hour \\ Triangular \\ Nishio 2015}

Nishio 2015

Nishio 2015

Based on FPInnovation Ash Application Cost Model, excluding equipment transportation costs (Nishio 2015) 
525 Table 2: Summary of model results for four wood ash disposal options.

\begin{tabular}{|c|c|c|c|c|c|c|c|c|}
\hline Model Item & $\begin{array}{c}\text { Ash } \\
\text { owne } \\
\text { Dispos }\end{array}$ & $\begin{array}{l}\text { ducer- } \\
\text { andfill } \\
\text { (Partial } \\
\text { e) }\end{array}$ & $\begin{array}{r}\text { Ash p } \\
\text { owned } \\
\text { Disposa }\end{array}$ & $\begin{array}{l}\text { ucer- } \\
\text { Indfill } \\
\text { ull Life) }\end{array}$ & $\begin{array}{r}\text { Munici } \\
\text { Di }\end{array}$ & $\begin{array}{l}\text { Landfill } \\
\text { sal }\end{array}$ & Forest $A$ & lication \\
\hline $\begin{array}{l}\text { @Risk Distribution } \\
\text { Ranges }\end{array}$ & $\begin{array}{l}\text { Low } \\
\text { Value }\end{array}$ & $\begin{array}{l}\text { High } \\
\text { Value }\end{array}$ & $\begin{array}{l}\text { Low } \\
\text { Value }\end{array}$ & $\begin{array}{l}\text { High } \\
\text { Value }\end{array}$ & $\begin{array}{l}\text { Low } \\
\text { Value }\end{array}$ & $\begin{array}{l}\text { High } \\
\text { Value }\end{array}$ & $\begin{array}{l}\text { Low } \\
\text { Value }\end{array}$ & $\begin{array}{l}\text { High } \\
\text { Value }\end{array}$ \\
\hline $\begin{array}{l}\text { Pre-Disposal Treatment } \\
\text { Costs (\$/tonne of ash) }\end{array}$ & $\$ 0$ & $\$ 0$ & $\$ 0$ & $\$ 0$ & $\$ 0$ & $\$ 0$ & $\$ 50$ & $\$ 96$ \\
\hline $\begin{array}{l}\text { Transportation Costs } \\
\text { (\$/tonne of ash) }\end{array}$ & $\$ 1$ & $\$ 5$ & $\$ 1$ & $\$ 5$ & $\$ 1$ & $\$ 10$ & $\$ 1$ & $\$ 11$ \\
\hline $\begin{array}{c}\text { Disposal Costs (\$/tonne of } \\
\text { ash) }\end{array}$ & $\$ 23$ & $\$ 188$ & $\$ 47$ & $\$ 281$ & $\$ 2$ & $\$ 394$ & $\$ 4$ & $\$ 34$ \\
\hline $\begin{array}{l}\text { Final Cost (\$/tonne of } \\
\text { ash) }\end{array}$ & $\$ 25$ & $\$ 190$ & $\$ 50$ & $\$ 283$ & $\$ 5$ & $\$ 399$ & $\$ 60$ & $\$ 128$ \\
\hline \multicolumn{9}{|c|}{$@$ Risk Distribution Results } \\
\hline Median (\$/tonne of ash) & \multicolumn{2}{|c|}{$\$ 77$} & \multicolumn{2}{|c|}{$\$ 136$} & \multicolumn{2}{|c|}{$\$ 108$} & \multicolumn{2}{|c|}{$\$ 92$} \\
\hline $\begin{array}{l}\text { Break-even Price (\$/tonne } \\
\text { of ash) }\end{array}$ & \multicolumn{2}{|c|}{$\$ 15$} & \multicolumn{2}{|c|}{$-\$ 44$} & \multicolumn{2}{|c|}{$-\$ 16$} & \multicolumn{2}{|c|}{ NA } \\
\hline
\end{tabular}

*Min and Max of @Risk Total Cost Distributions 
529 Preferred figure width: Fig. 1: 90 mm; Fig. 2, 3: 190 mm; Fig. 4,5: 140 mm

\section{Figure Captions}

532 Figure 1: The model outline showcases the cost categories for each of the three disposal options

533 examined.

534 Figure 2: Distribution of the base case model outputs for four wood ash disposal options.

535 Figure 3: Influence of primary model variables on base model outputs for four ash disposal 536 options: a) producer-owned landfill, partial lifetime, b) producer-owned landfill, full lifetime, c) 537 municipal landfill, and d) forest application.

538 Figure 4: Sensitivity analysis results for wood ash disposal under three different pre-disposal 539 treatment options. The base case scenario (the granulation treatment) is shown in solid green.

$540 \quad$ Figure 5: Sensitivity analysis results for four different assumptions regarding forest site 541 transportation distance. The base case scenario is shown in solid green. 


\section{$543 \quad$ Figure 1.}

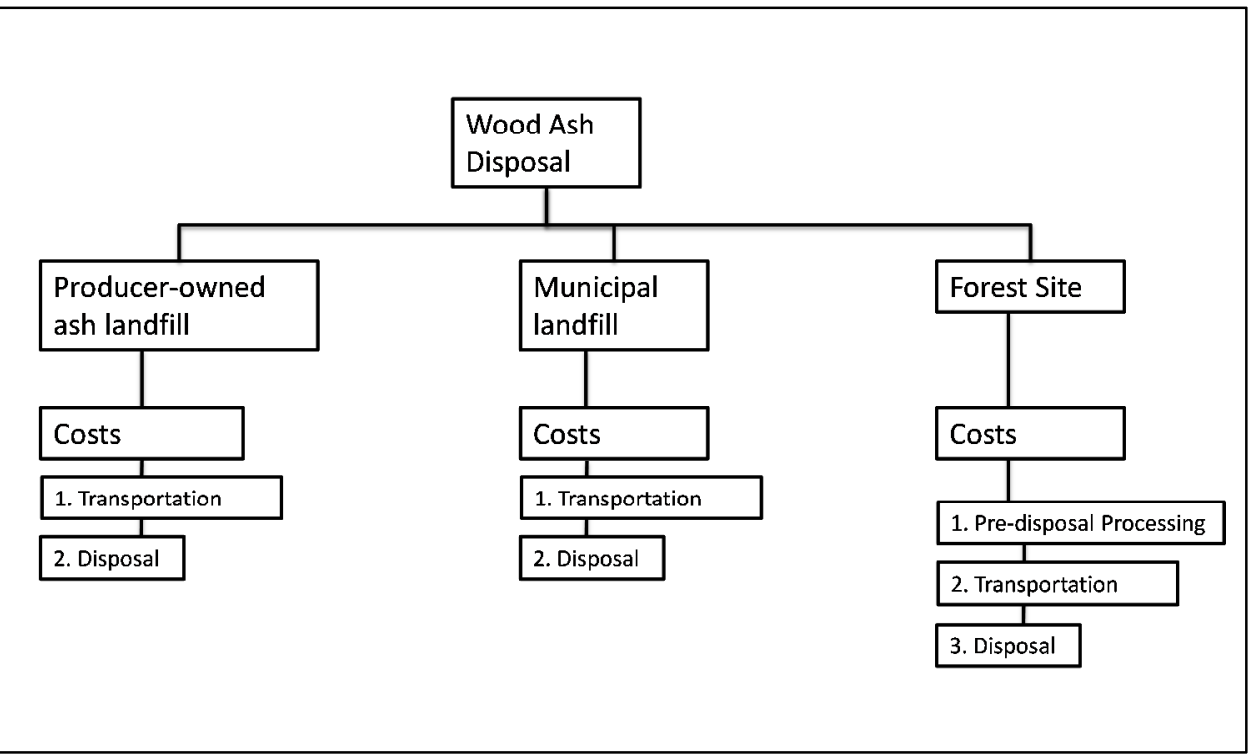

545 Figure 2.

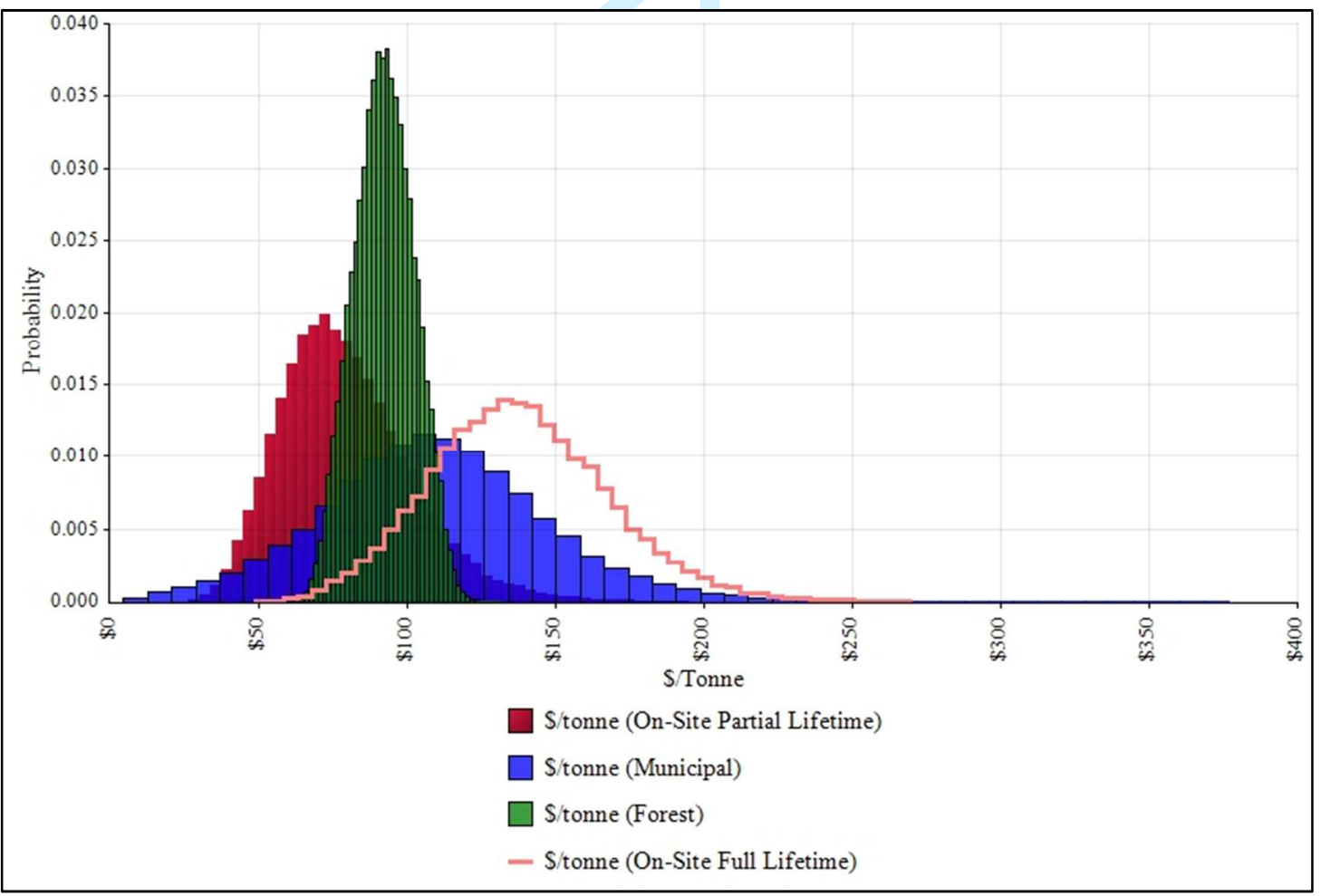




\section{Figure 3.}

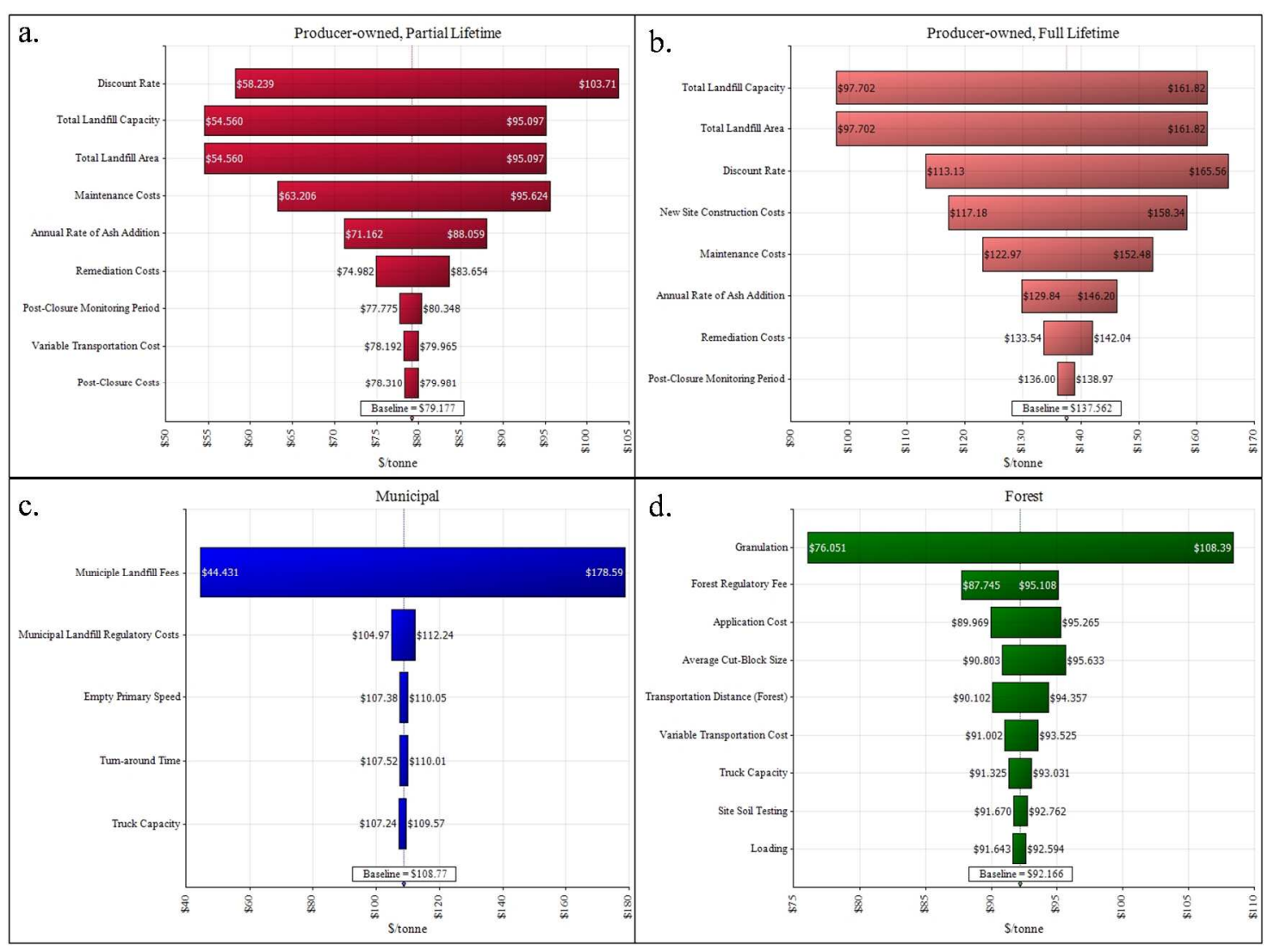

550

$551 \quad$ Figure 4.

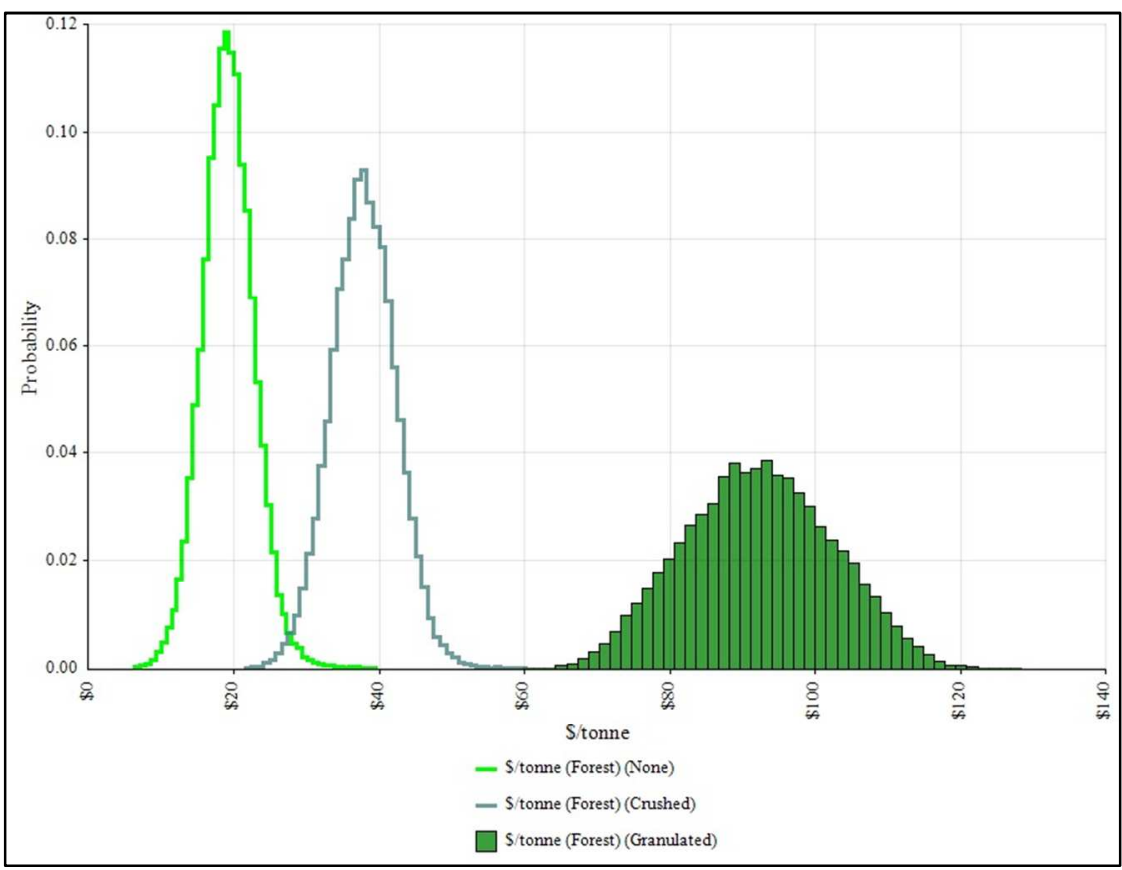




\section{$553 \quad$ Figure 5.}

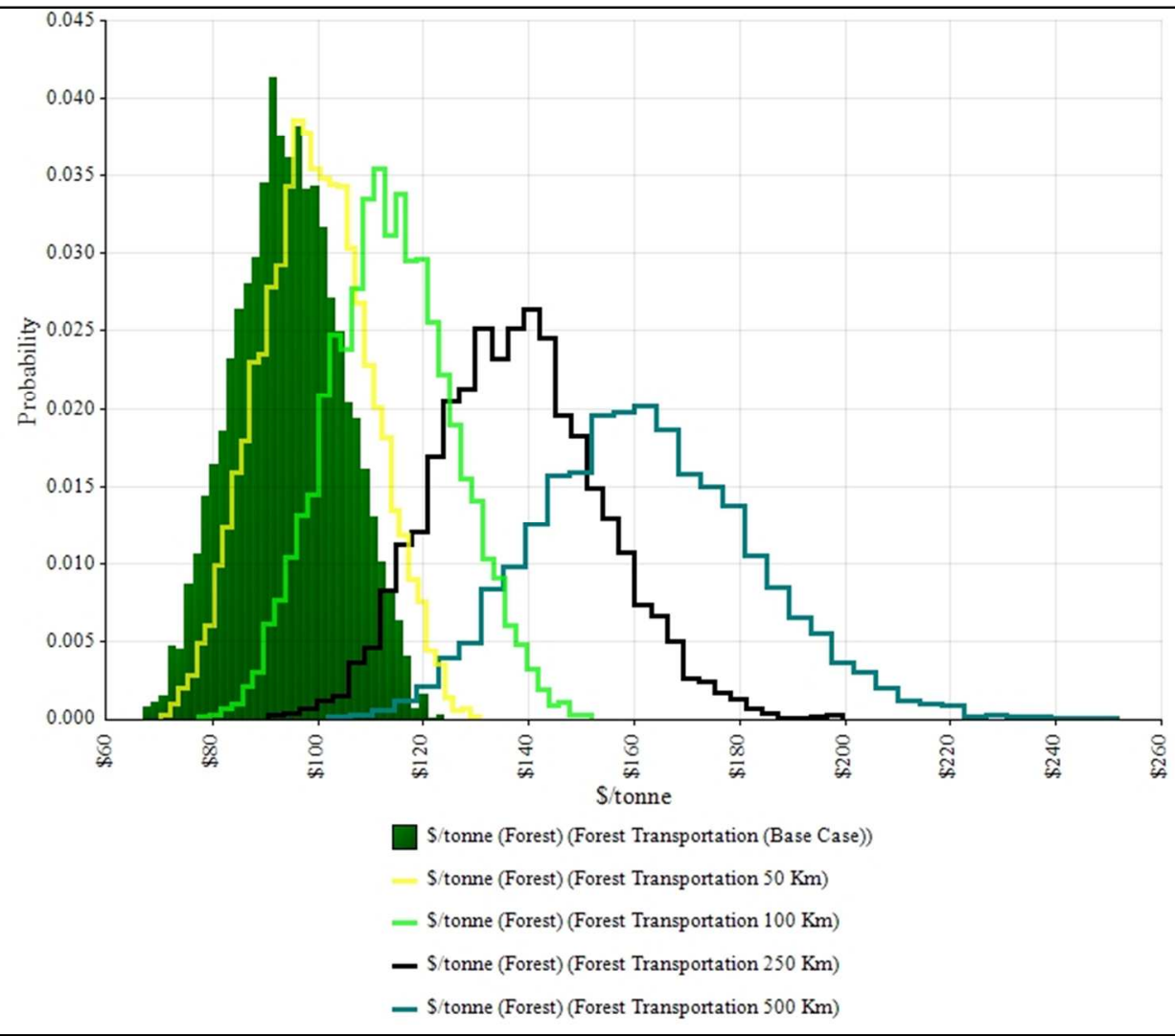

